\title{
Pembinaan Ibu Tentang Stimulasi Perkembangan Balita Islami Di Lingkungan Dasan Kolo Kota Mataram
}

\author{
Irni Setyawati, Agus Supinganto*, Kusniyati Utami \\ STIKes Yarsi Mataram, Indonesia \\ *agusping@gmail.com
}

\begin{abstract}
ABSTRAK
Tujuan dari kegiatan pengabdian kepada masyarakat ini adalah (1) Pendampingan stimulasi perkembangan balita melalui buku KIA (2) Pembinaan tata ruang Islami (3) Pembinaan sikap dan tingkah laku Islami. Mitra kerjasama kegiatan ini adalah kelompok ibu yang mempunyai Balita di Lingkungan Dasan Kolo Kecamatan Pagutan Kota Mataram. Metode pelaksanaan pengabdian kepada masyarakat terdiri dari tiga tahap yaitu persiapan, pelaksanaan dan evaluasi. Pada Tahap persiapan, tim pengabdian melakukan pra kunjungan ke tempat Mitra. Tahap Pelaksanaan terdiri dari kegiatan pre test dan penyuluhan dan pelatihan kepada kelompok ibu Balita tentang perkembangan tumbuh kembang Balita dan pembinaan tata ruang Islami. Tahap Evaluasi pelaksanaan kegiatan dilakukan dengan menilai tingkat keberhasilan penyuluhan dan pembinaan yang telah dilakukan. Hasil pengabdian membuktikan bahwa ibu balita sudah mampu memahami tumbuh kembang balita melalui buku KIA dan mampu memodifikasi ruangan secara Islami.
\end{abstract}

Kata Kunci: Pembinaan, Perkembangan Balita, Islami

\section{PENDAHULUAN}

Keluarga merupakan unit terkecil dalam masyarakat yang terdiri dari kepala keluarga dan beberapa orang yang berkumpul dan tinggal di bawah satu atap dalam keadaan saling ketergantungan (Harmoko, 2016). Masing-masing anggota keluarga seharusnya mampu meningkatkan fungsi kehidupannya sehingga dapat melaksanakan upaya kesehatan secara mandiri. Dalam keluarga terdapat fungsi sosialisasi pada anak, yaitu membentuk norma-norma tingkah laku sedini mungkin. Untuk membentuk pribadi seutuhnya yang mendukung terwujudnya keluarga sakinah, orangtua mempunyai tanggung jawab atas penyelenggaraan pembentukan jiwa agama pada anak-anak dengan mendidiknya menjadi muslim seutuhnya (Fathurrohman, 2016).

Masa lima tahun pertama kehidupan pada anak merupakan masa yang sangat peka terhadap lingkungan dan masa ini sangat pendek serta tidak dapat diulang lagi sehingga disebut sebagai masa keemasan (golden period), jendela kesempatan (window of opportunity), dan masa kritis (critical period)(Kemenkes RI, 2016). Pendidikan agama bagi anak-anak di dalam keluarga merupakan faktor yang sangat penting untuk 


\section{Journal of Community Engagement in Health}

perkembangan kepribadian anak sebab keluarga merupakan lingkungan pertama dan utama bagi anak. Selain pendidikan agama, pembinaan tumbuh kembang anak secara komprehensif dan berkualitas melalui stimulasi dapat merangsang otak balita untuk mengoptimalkan perkembangan kemampuan gerak, bicara dan bahasa, sosialisasi dan kemandirian pada balita.

Mayoritas penduduk di lingkungan Dasan Kolo kelurahan Jempong Baru Kecamatan Sekarbela Kota Mataram beragama Islam, namun penerapan pembinaan sikap dan tingkah laku Islami sejak anak berusia balita masih belum nampak. Setiap anggota keluarga masih belum membiasakan perilaku yang baik sebagai contoh bagi anak. Ibu sebagai pendidik pertama di dalam keluarga juga masih belum terbiasa menggunakan buku KIA sebagai panduan dalam memberikan stimulasi perkembangan anak. Hal ini dibuktikan dengan ibu tidak memahami cara menstimulasi perkembangan anak, baik perkembangan kemampuan gerak, bicara dan bahasa, sosialisasi dan kemandirian pada balita. Ibu beralasan tidak memiliki waktu untuk memberi stimulasi pada anak karena ibu harus berjualan di rumahnya sembari merawat anak.

Tugas ganda ibu sebagai pendidik anak dan pencari nafkah untuk membantu perekonomian keluarga inilah yang membuat ibu tidak memiliki banyak waktu atau menyediakan waktu khusus untuk dapat mengasuh dan mendidik anak secara maksimal. Sebagian besar suami ibu balita bekerja serabutan atau tidak tetap. Hal ini yang menyebabkan ibu berjualan di rumahnya.

Banyak diantara ibu-ibu balita yang masih belum memahami manfaat kepemilikan buku KIA bagi perkembangan anak. Ibu-ibu balita hanya memahami bahwa buku KIA wajib dibawa saat posyandu dan diisi oleh petugas posyandu, padahal didalam buku KIA telah disediakan cara menstimulasi perkembangan bayi usia 0-6 bulan, 6-12 bulan, anak usia 1-6 tahun. Selain itu, cara mendidik balita dengan sikap dan tingkah laku Islami belum dilakukan ibu balita dan keluarga secara maksimal.

Kurangnya pengetahuan dan kesadaran ibu dalam memberikan stimulasi pada balitanya menyebabkan perkembangan balita tidak menjadi perhatian ibu dan keluarga dalam kesehariannya. Lingkungan rumah dan tingkah laku ibu beserta anggota keluarga yang masih belum menggambarkan sikap dan tingkah laku Islami juga menjadi masalah dalam pola asuh sehari-hari ibu balita pada balitanya.

\section{BAHAN DAN METODE}

Kegiatan pada program kemitraan masyarakat Pembinaan ibu tentang pola asuh perkembangan balita Islami di lingkungan Dasan Kolo kelurahan Jempong Baru kota Mataram yaitu (i) Pre test (ii) Pendampingan stimulasi perkembangan balita melalui buku KIA (iii) Pembinaan tata ruang Islami (iv) Pendampingan sikap dan tingkah laku Islami (v) Pembagian buku saku perkembangan balita Islami (vi) Evaluasi dan monitoring setiap 4 minggu selama 3 bulan. Bahan dan alat yang dibutuhkan untuk mengadakan pelatihan adalah seperangkat peralatan untuk presentasi berupa Buku saku, LCD, laptop, leaflet, dan kamera.

\section{HASIL DAN PEMBAHASAN}

Program kemitraan masyarakat ini dilakukan di lingkungan Dasan Kolo kelurahan Sekarbela Kota Mataram dengan tema "Pembinaan ibu tentang pola asuh perkembangan balita Islami di lingkungan Dasan Kolo kelurahan Jempong Baru kota Mataram" yang diikuti oleh 13 orang ibu dan balita. Kegiatan ini dilaksanakan selama 3 bulan dengan rincian kegiatan sebagai berikut: 


\section{Journal of Community Engagement in Health}

http://jceh.org

ISSN: 2620-3758 (print); 2620-3766 (online)

https://doi.org/10.30994/jceh.v3i2.50

Vol.3 No.2. Sep 2020. Page.129-135

1). Pretes pengetahuan ibu tentang stimulasi perkembangan balita melalui buku KIA, tata ruang Islami, sikap dan tingkah laku Islami. Kegiatan pretes dilakukan di rumah masing-masing ibu balita selama 5 hari dari tanggal 16 sampai dengan 20 September 2019 dengan rincian pretes pada 3 orang ibu Balita per harinya. Adapun hasil pretes ibu tentang stimulasi perkembangan balita melalui buku KIA, tata ruang Islami, sikap dan tingkah laku Islami yaitu pengetahuan tentang stimulasi perkembangan Balita 77\% ibu Balita masih kurang tentang perkembangan Balita. Penataan ruang, sikap dan tingkah laku Islami sudah cukup yaitu 61,5\%.

Pengetahuan merupakan awal dari proses perubahan perilaku. Bila seorang ibu balita mempunyai pengetahuan yang cukup atau bahkan baik tentang cara stimulasi perkembangan balita, maka ibu balita mampu melakukan stimulasi perkembangan balita sesuai dengan usianya. Pendapat (Notoatmodjo, 2010) menyatakan bahwa pengetahuan dan kesadaran merupakan dasar dari tindakan pemeliharaan dan peningkatan kesehatan, namun proses ini membutuhkan waktu yang cukup lama untuk dapat menghasilkan perubahan perilaku. Selanjutnya (Kharisma \& Efni, 2017) menyatakan ada hubungan antara pengetahuan ibu dan perkembangan anak di kota Jambi yang ditunjukkan dengan semakin rendah pengetahuan ibu maka anak semakin berisiko mengalami keterlambatan perkembangan.

Pengetahuan ibu tentang tata ruang, sikap dan tingkah laku Islami sama pentingnya dengan pengetahuan ibu tentang perkembangan balita. Pengetahuan ibu balita tentang tata ruang, sikap dan tingkah laku Islami sebagian besar dalam kategori cukup. Hal ini dapat disebabkan oleh pemahaman ibu Balita terhadap agamanya yang dipraktekkan dalam kebiasaan sehari-hari. Penelitian (Puspitasari et al., 2015) menemukan adanya hubungan yang signifikan antara pola asuh spiritual ibu dan karakter moral anak, semakin sering ibu memberikan pola asuh spiritual pada anak, maka karakter yang dimiliki anak akan semakin meningkat.

2). Pendampingan ibu balita tentang stimulasi perkembangan balita melalui buku KIA dan pembinaan tata ruang, sikap dan tingkah laku Islami.

Kegiatan pendampingan ibu balita tentang stimulasi perkembangan balita dilakukan dengan praktik langsung ke balitanya masing-masing menggunakan alat permainan edukatif milik pribadi. Kegiatan ini dilakukan selama 5 hari dari tanggal 23 sampai dengan tanggal 27 September 2019. Stimulasi perkembangan balita disesuaikan dengan kelompok usia balita ibu. Perkembangan yang distimulasi meliputi perkembangan kemampuan gerakan kasar, kemampuan gerakan halus, kemampuan berbicara dan bahasa, dan kemampuan bersosialisasi.

Selain pendampingan stimulasi perkembangan balita, pembinaan tata ruang, sikap dan tingkah laku Islami juga dilakukan selama 5 hari dari tanggal 30 September 2019 sampai dengan 4 Oktober 2019. Khusus untuk pembinaan tata ruang tidak memaksakan kondisi rumah ibu balita dengan menambah ruang khusus sholat berjamaah, namun hanya menyediakan kamar khusus untuk sholat bagi anggota keluarga perempuan, dan sholat berjamaah di masjid bagi anggota keluarga laki-laki.

Pembinaan tata ruang Islami yang dimaksud pada kegiatan PKM ini meliputi:

a. Menempelkan tulisan

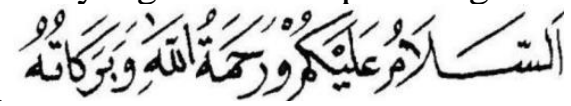

atau Assalamu'alaikum Warahmatullahi Wabarakaatuh di pintu rumah. 
b. Ruang tamu selalu bersih dan teratur dihiasi dengan tulisan:
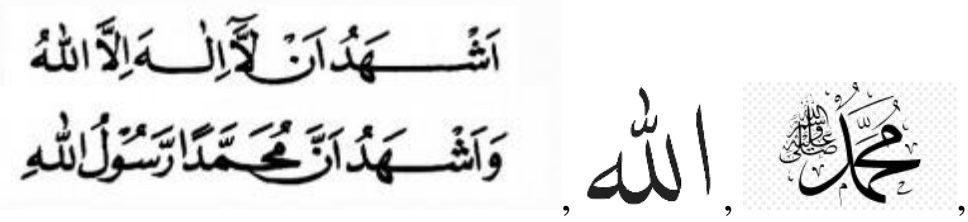

atau gambar masjid, gambar Ka'bah.

c. Ruang keluarga, kamar tidur dan dapur tidak dihiasi dengan gambar non Islami, namun tulisan doa-doa, seperti doa sebelum masuk dan sesudah keluar kamar mandi, doa sebelum dan sesudah makan, doa sebelum dan bangun tidur, doa akan belajar, doa masuk dan keluar rumah, doa saat turun hujan, dll.

d. Ada ruangan khusus untuk sholat jamaah, dihiasi dengan tulisan peringatan, seperti shalatlah berjamaah, bacalah Al-Qur'an, shalatlah tepat pada waktunya.

Pembinaan sikap dan tingkah laku Islami pada kegiatan PKM ini yaitu mengajak ibu Balita untuk membiasakan perkataan, perbuatan, pergaulan, dan amal ibadah setiap anggota keluarga, khususnya balita yang sedang diasuhnya mencerminkan keimanan dan ketaqwaan kepada Allah Subhanallahu Wa Ta'ala dan ittiba' Rasulullah Shalallahu 'Alaihi Wassalam. Adapun kebiasaan yang perlu diamalkan seperti berikut:

a. Kebiasaan berdoa di semua kegiatan

b. Membiasakan ucapan kalimat thayyibah, misalnya

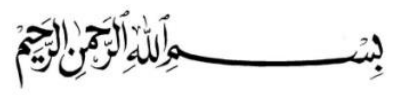

, bila hendak memulai suatu kegiatan

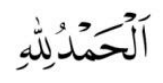

, bila telah melakukan pekerjaan atau memperoleh kenikmatan

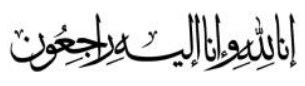

, bila mendapat musibah

سُبْحَانَ اللّهُ

, bila terjadi hal yang mengejutkan

ماشثاللَّة

, bila terjadi sesuatu yang mengagumkan

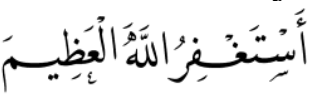

, bila melakukan kesalahan

انشُأكئ: bila berhasil melakukan pekerjaan sesuai dengan yang diharapkan

c. Mengucapkan

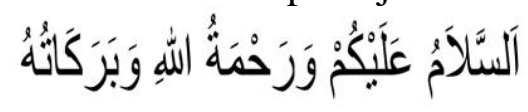

rumah dan menjawab salam

saat masuk dan meninggalkan

d. Berpakaian sopan sesuai dengan ajaran Islam baik di rumah maupun bepergian 


\section{Journal of Community Engagement in Health}

http://jceh.org

ISSN: 2620-3758 (print); 2620-3766 (online)

https://doi.org/10.30994/jceh.v3i2.50

Vol.3 No.2. Sep 2020. Page.129-135

e. Menghibur anak-anak saat menjelang tidur dengan membacakan dongeng pengantar tidur, misalnya riwayat nabi-nabi atau cerita akhlak mulia dan diakhiri dengan doa sebelum tidur

3). Pembagian buku saku perkembangan balita Islami kepada ibu balita yang digunakan sebagai alat bantu praktik dilakukan pada tanggal 7 sampai dengan 11 Oktober 2019 di rumah masing-masing ibu Balita. Pada kegiatan ini tidak hanya membagikan buku saku, namun sekaligus dilakukan penjelasan tentang isi buku saku yang terdiri dari cara stimulasi perkembangan bayi sesuai usia dan pembinaan tata ruang, sikap dan tingkah laku Islami di keluarga.

4 ). Evaluasi dan monitoring setiap 4 minggu selama 3 bulan

Kegiatan monitoring dilakukan setiap 4 minggu sekali yaitu pada tanggal 14-18 Oktober 2019, 18-22 November 2019 dan 23-27 Desember 2019. Monitoring perubahan pola asuh ibu dan keluarga kepada balitanya dilakukan dengan menggunakan metode pendokumentasian secara SOAP (Subyektif, Obyektif, Analisa, dan Penatalaksanaan). Sebagian besar ibu balita telah mampu melakukan stimulasi perkembangan balita. Demikian pula dengan pembinaan tata ruang dan sikap serta tingkah laku Islami. Hal ini ditunjukkan dengan rumah ibu balita yang telah ditempeli tulisan doa-doa harian di dinding rumahnya.

Berdasarkan hasil evaluasi tata ruang Islami di atas dapat dilihat bahwa ibu balita telah mampu mempraktekkan saran mahasiswa selama proses pendampingan. Hal ini menunjukkan adanya perubahan perilaku ibu balita ke arah yang positif. Hasil Penelitian (Padjrin, 2016) menyebutkan bahwa membimbing balita memerlukan kesabaran dan ketelatenan orangtua khususnya dalam mengajarkan kalimat-kalimat pendek Islam yang sering diucapkan sehari-hari karena pada masa ini orangtua masih dianggap sebagai teladan atau contoh bagi balita. Pendapat (Aji et al., 2016) bahwa usia 0-7 tahun merupakan pondasi aqidah bagi setiap anak yang dimulai dari suara adzan dan iqamah yang diperdengarkan orangtuanya saat bayi baru lahir. Selanjutnya tergantung pada stimulasi yang diberikan oleh orangtua dengan meneladani pola asuh Rasulullah SAW dalam mendidik anak dengan penuh kasih sayang.

Kegiatan evaluasi dilakukan pada tanggal 23-27 Desember 2019 dengan kunjungan rumah secara langsung. Pada kegiatan ini perkembangan balita diukur secara langsung (observasi) dengan enggunakan Kuesioner Pra Skrining Perkembangan (KPSP) sesuai usia masing-masing Balita.Disamping melakukan evaluasi, ibu juga diajarkan cara mengevaluasi perkembangan kemampuan dasar balita dengan menggunakan buku KIA yang telah dimiliki ibu. Dalam buku pedoman yang dikeluarkan (Kemenkes RI, 2016) telah membagi evaluasi perkembangan balita pada usia 1 bulan, 3 bulan, 6 bulan, 9 bulan, 12 bulan, 2 tahun, 3 tahun, 5 tahun dan 6 tahun.

Selain perkembangan balita, pengetahuan ibu balita tentang stimulasi perkembangan balita, tata ruang, sikap dan tingkah laku Islami juga diukur kembali dengan menggunakan angket pada kegiatan evaluasi ini. Adapun hasil pengetahuan ibu adalah sebagai berikut, Berdasarkan hasil evaluasi pengetahuan ibu tentang stimulasi perkembangan balita dan tata ruang, sikap dan tingkah laku Islami diperoleh hasil sebagian besar ibu balita mempunyai pengetahuan baik tentang stimulasi perkembangan balita sebesar 69,2\% dan sebagian besar ibu balita mempunyai pengetahuan baik tentang tata ruang, sikap dan tingkah laku sebesar 84,6\%. Bila dibandingkan dengan hasil pretes di awal pertemuan, pengetahuan ibu balita mengalami peningkatan, yaitu sebagian besar mempunyai pengetahuan kurang tentang stimulasi perkembangan balita (77\%) dan sebagian besar ibu balita mempunyai pengetahuan yang cukup tentang tata ruang, sikap 


\section{Journal of Community Engagement in Health}

dan tingkah laku Islami (61,5\%). (Aji et al., 2016) mendapat hasil bahwa pengetahuan ibu Balita mempengaruhi perilaku pola asuh ibu. Pola asuh yang baik sangat mempengaruhi perkembangan Balita.

Selain peningkatan pengetahuan ibu balita, perkembangan kemampuan dasar balita yang diperiksa dengan menggunakan instrumen KPSP menemukan hasil bahwa perkembangan seluruh balita dalam kategori sesuai. Hal ini menunjukkan bahwa proses pendampingan mahasiswa kepada ibu balita mempunyai peranan penting dalam merubah pengetahuan, sikap dan perilaku ibu balita. Beberapa faktor yang mempengaruhi perilaku stimulasi ibu balita terhadap perkembangan balitanya yaitu tenaga kesehatan, komunikasi dan konseling tenaga kesehatan, dan motivasi dan minat dari masyarakat. Pendampingan mahasiswa dalam pengabdian kepada masyarakat ini dapat dianggap sebagai tenaga kesehatan dan komunikasi serta konselingnya (Fitriani \& Oktobriariani, 2017). Mahasiswa berperan sebagai tenaga kesehatan dan proses pendampingan kepada ibu balita selama 4 bulan sebagai proses komunikasi dan konseling.

Pengabdian kepada masyarakat di desa Mayong Lor Jepara yang dilakukan (Rahmawati, 2019) memperoleh hasil masyarakatnya dapat melakukan stimulasi perkembangan kemampuan motorik balita setelah dilakukan pelatihan. Kegiatan pelatihan seperti ini merupakan salah satu upaya untuk meningkatkan pengetahuan dan perilaku ibu dalam memberikan stimulasi pada balitanya. Kementerian Kesehatan RI telah mengatur pemantauan pertumbuhan, perkembangan dan gangguan tumbuh kembang anak sejak usia nol sampai dengan 72 bulan dalam Peraturan Menteri Kesehatan RI nomor 66 tahun 2014 (Kemenkes RI, 2014).

\section{KESIMPULAN DAN SARAN}

Kegiatan program kemitraan masyarakat "Pembinaan ibu tentang pola asuh perkembangan balita Islami di lingkungan Dasan Kolo kelurahan Jempong Baru kota Mataram" meliputi (i) Pre test (ii) Pendampingan stimulasi perkembangan balita melalui buku KIA (iii) Pembinaan tata ruang Islami (iv) Pendampingan sikap dan tingkah laku Islami (v) Pembagian buku saku perkembangan balita Islami (vi) Evaluasi dan monitoring setiap 2 minggu selama 2 bulan ini telah meningkatkan pemahaman dan implementasi stimulasi perkembangan balita, tata ruang dan tingkah laku Islami di keluarga ibu Balita.

\section{UCAPAN TERIMA KASIH}

Ucapan terimakasih disampaikan kepada Kepala Lingkungan Dasan Kolo Kelurahan Sukarbela Kota Mataram, Kepala Puskesmas karang Pule Kota Mataram yang telah mendukung dan memberikan fasilitas dan kepada Civitas Akedimika Stikes Yarsi Mataram serta kader dan seluruh kelompok Ibu Balita yang telah berperan serta dalam kegiatan Pengabdian Masyarakat ini. Evaluasi program pelatihan dengan dukungan tokoh masyarakat selanjutnya perlu ditingkatkan dan peran serta institusi pendidikan dalam pendampingan untuk masyarakat bekerjasama dengan kader kesehatan penting untuk di lakukan. 


\section{Journal of Community Engagement in Health}

http://jceh.org

ISSN: 2620-3758 (print); 2620-3766 (online)

https://doi.org/10.30994/jceh.v3i2.50

Vol.3 No.2. Sep 2020. Page.129-135

\section{REFERENSI}

Aji, Dimas setiyo Kusuma, Wati, Erna Kusuma, \& Rahardjo, S. (2016). Factors Analysis That Affect Parenting Under Five Years At Banyumas District. Jurnal Kesmas Indonesia, 8 no. $1,1-15$.

Fathurrohman. (2016). Pembinaan Keluarga Sakinah. 1-6.

Fitriani, S., \& Oktobriariani, R. R. (2017). Stimulasi, Deteksi dan Intervensi Dini Orang Tua terhadap Pencegahan Penyimpangan Pertumbuhan dan Perkembangan Anak Balita. Indonesian Journal for Health Sciences, 1(1), 1-9. https://doi.org/10.24269/ijhs.v1i1.2017.pp10-16

Harmoko. (2016). Asuhan Keperawatan Keluarga. Pustaka Pelajar.

Kemenkes RI. (2014). Peraturan Menteri Kesehatan Republik Indonesia Nomor 66 Tahun 2014 Tentang Pemantauan Pertumbuhan, Perkembangan, Dan Gangguan Tumbuh Kembang Anak. Berita Negara Republik Indonesia Tahun 2014 Nomor 1524, 365. https://doi.org/10.1017/CBO9781107415324.004

Kemenkes RI. (2016). Buku KIA 2016.

Kharisma, M., \& Efni, N. (2017). Hubungan Pengetahuan Ibu Tentang Tumbuh Kembang Dengan Perkembangan Anak Usia 3-4 Tahun. 6(1), 26-39.

Notoatmodjo, S. (2010). Promosi Kesehatan Teori dan Aplikasi. Rineka Cipta.

Padjrin, P. (2016). Pola Asuh Anak dalam Perspektif Pendidikan Islam. Intelektualita, 5(1), 1. https://doi.org/10.19109/intelektualita.v5i1.720

Puspitasari, R., Hastuti, D., \& Herawati, T. (2015). Pengaruh Pola Asuh Disiplin Dan Pola Asuh Spiritual Ibu Terhadap Karakter Anak Usia Sekolah Dasar. 2, 208-218. https://doi.org/10.21831/jpk.v0i2.8624

Rahmawati, I. (2019). Pendampingan Ibu Dalam Stimulasi Perkembangan Motorik Untuk Mengoptimalkan Perkembangan Balita Di Desa Mayong Lor Kecamatan Mayong Kabupaten Jepara. Amaliah: Jurnal Pengabdian 